DOI: https://doi.org/10.47264/idea.lassij/4.1.22

Vol. 4, No. 1, (January-June 2020): 255-270

Research Article

URL: https://www.ideapublishers.org/index.php/lassij

\title{
Attitude and Perception of Women on Domestic Violence Practiced by Husbands in Ethiopia
}

\author{
Rata Bayissa* \\ Department of Gender \& Development, College of Social Sciences, Haramaya Huniversity, Ethiopia.
}

Received: September 4, 2019

Published Online: December 10, 2020

\begin{abstract}
This study assesses women's attitudes and perceptions of domestic violence that are practiced in different communities with a variety of cultures. The study investigates the causes and impacts of domestic and gender-based violence on women's life in Ethiopia. The study also investigates the attitude and perceptions of the women towards their experiences of domestic and gender base violence. This study specifically aims to examine the perception and attitudes of the women towards domestic violence in East Hararghe Zone, Ethiopia. The study also aims to analyse the common types of domestic violence and the response of communities towards the domestic violence in the study area. Purposive and convenient sampling is used to determine selection of the respondents. In-depth interview tool for focus group discussion is used to collect the data and analyse it thematically. A significant number of women respondents consider that violence against women is the usual conflict between the wife and the husband that could happen anywhere in the male dominated societies.
\end{abstract}

Keywords: Women Issues, Gender Based Violence, Domestic Violence, Violence against Women, Gender Issues in Ethiopia.

\section{Introduction}

Domestic issue and gender based violence is one of the social issues which mostly affect the women across the world. Though its practice is dynamic from one place to the other depending on the implementation capacity of each country in addressing the issues and also with their level of commitment, the problem is pervasive and widely practiced in all cultures and society. The case is also similar with that of Ethiopia in general and study site in particular. The issue do not affect only the victims, but it also deteriorate the country's development at all. This is because women consists of half of the world's total population and with the exclusion of them, it is hard to realize the development and that is why many researchers have always brought the issue to the spot. It is a from this perspective that this research has been conducted with the intention of having various benefits to the women, their children and family, and the concerned government bodies, nongovernment, parents' of women, the society as well as academic world.

Accordingly, this study would serve the government to re-investigate the issues of domestic gender based violence and its different impacts on women at national level and used as an input for them to allocate gender responsive budget which is expected to be implemented on addressing gender issues and realize gender equality at most. The outcome of this study would 
also support the women to get insight about how domestic violence issue differently affect their life and then prepare them to struggle for their right. In addition to this, the study serves to show the extent to which women are affected by the socially constructed gender issues that leads to the practices and would be expected to push nongovernmental organization to deeply engage on mitigating the issue. Moreover, the study is profoundly also used as a reference for the researcher whose research interests are in line to this study and want to conduct further study on or similar areas. This study was geographically delimited to selected areas of East Hararghe Zone that was purposely selected among other towns based on the population size and socio-economic and political consciousness and participation of the community in the town hoping that the selected respondents from the site would provide sufficient and quality data. In addition to this, the study was also conceptually delimited to studying the attitude and perception of women on domestic violence practiced by their husbands.

Violence against women is the most pervasive yet least recognized human rights violation in the world. It is also a profound health problem for women, sapping women's energy, compromising their physical health, and eroding their self-esteem. In addition to causing injury, violence increases women's long-term risk of several other health problems, including chronic pain, physical disability, drug, and alcohol abuse, and depression. Women with a history of physical or sexual abuse are also at increased risk of unintended pregnancy, sexually transmitted infections (STIs), and adverse pregnancy outcomes. Despite its high costs, almost every society in the world has social institutions that delegitimize, obscure, and deny the abuse. The same acts that would be punished if directed at an employer, a neighbour, or an acquaintance often go unchallenged when men direct them at women, especially within the family (Heise et al., 1999).

Women's advocacy groups around the world have been working to draw more attention to the physical, psychological, and sexual abuse of women and to stress the need for action. They have provided shelter for abused women, lobbied for legal reforms, and challenged the widespread attitudes and beliefs that support violent behaviour against women. The violence, among other things, includes battering, burning, emotional blackmail, mockery or ridicule, threats of abandonment, confinement to the home, and the withholding of money and other family support. Partner violence occurs in all countries and transcends social, economic, religious, and cultural groups. One of the most common forms of violence against women across the world is abuse by their husbands or other intimate male partners (WHO, 2019). The issue is pervasive in developing countries, especially sub-Saharan countries such as Ethiopia. About one-half to two-thirds of women experience one or other forms of spousal abuse at least once in their lifetime in Ethiopia (Birtukan, 2014). The spousal violence is a serious public health concern, as it is associated with a number of health consequences for the women victims. The negative impact of this violence extends beyond the women's sexual and reproductive health to their overall health, the welfare of their children, and the economic and social fabric of the nations.

In many cultures, men have the right to control the behaviour of their spouse, and women who challenge that right may face social punishment (DAHS, 2002). For example, domestic violence as often viewed as a mechanism through which a man corrects his wife and is believed to be the right thing for him to do. According to Demographic and Health Survey (2016) of Ethiopia, 85\% of women argue that their husband is justified in beating his wife for at least one reason. Several studies examined the prevalence and consequences of Gender 
Based Violence (GBV) in Ethiopia and other developing countries. However, only a few of them focus on domestic violence in the country. Therefore, the current study assessed the attitude and perception of women toward domestic violence in Ethiopia, East Hararghe Zone.

\subsection{Violence against Women}

Violence against Women (VAW) is a public health problem prevailing globally, particularly in the developing countries including, Ethiopia. Accordingly, Sustainable Development Goal (SDG) number five prioritizes the violence against women and calls for the design and implementation of programs which relevant to its elimination by 2030 (Getachew, 2018). The most pervasive form of gender-based violence is domestic that abuse of women by intimate male partners. A recent review of 50 population-based studies carried out in 36 countries indicates that between 10 and $60 \%$ of women who have ever been married or partnered have experienced at least one incident of physical violence from a current or former intimate partner. Although women can also be violent and abuse exists in some same-sex relationships, the vast majority of partner abuses are by men against their female partners (Immigration and Refugee Board of Canada, 2004).

Various studies indicated the prevalence and impact of violence against women in Ethiopia. For example, 50-60\% of women in the country experienced domestic violence in their life; and sexual violence is the prevalent form of violence (Yemaneh, 2004). Ruth (2017) assessed the response of the communities towards domestic violence and found that violence against women at home is very high. But the women who are the victim at first hand cooperate with the issues and prefer to be silent than challenging it. Besides, a study conducted by Birtukan (2014) on the carrier experience and advancement opportunities of women housemaids in Addis Ababa found that domestic violence is increasing tremendously in Addis Ababa on housemaids with no tangible attention to address the issues. Moreover, Demmelash (2012) found that most community of the country does not seriously take GBV as violence. The community discouraged the women from going to court and instead recommended them to resolve it through community elders.

However, the studies focused on assessing the impacts of domestic violence and failed to consider more specifically the contribution of the community's and women's attitudes and perception in perpetuating domestic violence in the country. Therefore, this study aims to fill the gap by assessing the perception and attitude towards domestic violence in Ethiopia, East Hararghe Zone.

\subsection{Domestic Gender-Based Violence}

Gender as socially constructed norms and ideologies that determine the behaviour and actions of men and women (WDR, 2012). GBV is a phenomenon deeply rooted in gender inequality and continues to be one of the most notable human rights violations within all societies. The researcher found ECOSOC Humanitarian Affairs Segment (2006) definition as the most expressive, according to which GBV is any form of violence used to establish, enforce, or perpetuate unequal gender power relations. The document defines as a harmful act that perpetrates against a person's will based on socially associated differences between males and females'. Hence, violence occurs due to socially ascribed differences, gender-based violence includes, but is not limited to sexual violence. While women and girls of all ages make up the 
majority of the victims, men and boys are also both direct and indirect victims. It is clear that the effects of such violence are both physical and psychological, and have long term detrimental consequences for both the survivors and their communities.

GBV is an umbrella term that encompasses those types of intimate partner violence (IPV) and non-partner rape, as well as a range of violent acts of other physical, psychological, economic, and sexual violence, exploitive or coercive acts, as well as harmful traditional practices. The term "gender-based violence" is often used interchangeably with the term "violence against women." The term highlights the gender dimension of these types of acts in other words, the relationship between women's subordinate status in society and their increased vulnerability to violence (IASC, 2005). But GBV against men is a reality too. What happens to women and children also happens to men though less often, probably more brutal, but less visible than GBV committed against women. GBV is prevalent not specifically among conflict-affected populations like refugees and is related to multifarious levels of vulnerability of conflict and displacement (Hiba, 2018). GBV today has emerged as a widespread problem among refugees and is acknowledged as a gross violation of human rights and public health issue worldwide (UNFPA, 2017). Although, GBV cannot be ascribed to a single cause to various set of dynamics, little is known about how vulnerable men and women refugees are to GBV or how they negotiate their way in an urban environment.

The Istanbul Convention (2011) of the Council of Europe, Convention on preventing and combating violence against women and domestic violence defines violence against women as categorized under four notable forms: physical, sexual, psychological, and economic. Physical violence is any act which causes bodily harm as a result of unlawful physical force. Physical violence can take the form of, among others, major and minor assault, deprivation of liberty, and manslaughter. Sexual violence is any sexual act performed on an individual without his or her consent. Sexual violence can take the form of rape or sexual assault. Psychological violence is any act which causes psychological harm to an individual. Psychological violence can take the form of, for example, coercion, defamation, verbal insult, or harassment. Economic violence is any act or behaviour which causes economic harm to an individual. An act of economic violence can take the form of property damage, restricting access to financial resources, education or the labour market, or not complying with economic responsibilities, such as alimony. It is also pertinent to recognize that gender-based violence may be aggravated and reproduced due to structural inequalities, such as societal norms, attitudes, and stereotypes around gender generally and violence against women specifically.

\subsection{Domestic Gender-Based Violence in Ethiopia}

According to Garcia-Moreno et al., (2005), Gender Based Violence significantly affects women by $10-60 \%$ in their life span. As some of the recently conducted research indicated, Ethiopia is one among different countries which have a high prevalence of domestic genderbased violence, especially among countries included in the WHO and results from numerous community-based studies indicate that $50 \%$ to $60 \%$ of Ethiopian women experience genderbased violence in their lifetime (Birhane, 2004). Research in Ethiopia shows that the domestic and gender-based violence has increased due to a culture of male dominance. These perceptions and attitudes, found among both men and women, inculcate the acceptance of men's sexually and physically abusing of the women. Physical punishment of women is known to begin in the childhood. Notably, the investigators have reported that fathers, brothers, and other male 
relatives believe that it is their responsibility to beat girls and young women as a way to shape their behaviour and attitude (Berhane, 2004; Gossaye et al., 2003).

\section{Theoretical Framework}

Researchers can use different forms of approaches, frameworks and theories based on the type of study they wish to conduct and also the methodology they want to apply. One of the theories rooted in gender inequality and gender-based violence is Feminist theory that would serve as a theoretical framework for studies dealing with the perception and attitude of the community towards domestic gender-based violence afflicting the women, especially by their husbands. This study used the feminist theory, one of the most liberal and radical concepts of feminism as one of the theoretical frameworks. The researcher believed this theory could demonstrate about the causes of domestic issues of women and gender-based violence and the community's attitude and perception regarding the issue that has a pivotal role to play in addressing the problem at the grass-root level. Accordingly, feminism is defined as a theory that examines the gender inequality, women's social roles, experiences, interests, and chores in various fields such as anthropology, sociology, communication, psychoanalysis, political science, home economics, literature, and philosophy. The basic definition of feminism is that men and women should be equal in all aspects including politically, economically, and socially. Feminism is such a widespread and complex theory, for this particular study, the researcher used two types of theories: radical and liberal feminism.

The radical perspective of feminism is that calls for a radical reordering of the male supremacist society and eliminating the gender inequality in all social and economic contexts. According to Sheila (2014), the feminist theorists do not seek to make gender a bit more flexible, but to abolish it. They are gender abolitionists and understand the gender to provide the framework and rationale for male dominance. Radical feminists want to free both men and women from the rigid gender roles that society has imposed upon them. The sex-gender system has created oppression whereas radical feminist's mission is to overthrow this system by any possible means.

Liberal perspective of feminism can be defined as an individualist form of feminist theory. Liberal feminists argue that society holds the false belief that women are intellectually and physically less capable than men because of nature. This wrong belief creates discrimination in academy, marketplace, political area, sportive activities, social life, etc. So, liberal feminists believe that female subordination is rooted in a set of customary and legal constraints that blocks women's entrance to and success in the so-called public world. Liberal feminists create and support acts of legislation that remove the barriers for women. They strive for sexual equality via political and legal reform. These acts of legislation demand equal opportunities and rights for women, including equal access to jobs and equal pay. Liberal feminists believe that removing these barriers directly challenges the ideologies of patriarchy, as well as liberates women. Both theories are intended to remove the gender inequality and patriarchal system in which men dominated and oppress women that gradually leads to gender-based violence.

\section{Research Design and Methods}

\subsection{The Study Area}

East Hararghe is one of the Zones of the Region of Oromia. It takes its name from the former 
province of Hararghe. It is bordered on the southwest by the Shebelle River which separates it from Bale, on the west by Mirab Hararge, on the north by Diredhawa, and the north and east by the Somali Region. The Harari Region is an enclave inside this zone. The Administrative center of this zone is Harar. Towns and cities in East Hararghe include Deder, Haramaya, Awaday, Babille, and Funyan Bira. Its highest point is Gara Muleta. Local landmarks include the Harar Wildlife Sanctuary and Haramaya University.

\subsection{Research Design}

The research design is an exploratory. This design enables the researcher to conduct an indepth study to understand attitudes and perceptions toward domestic violence, as there are few prior studies on the topic. According to Marican (2006), the exploratory study design is vital when there are few or no earlier studies to refer to predict the outcome. The focus is on gaining insights and familiarity for later investigation when research problems are in a preliminary stage of the investigation. In addition to this, the study used a qualitative research approach because it follows the feminist research approach.

\subsection{Population of the Study}

The study population consists of women; both married and divorced who have experienced domestic violence in their life, selected from Eastern Hararghe zone, particularly Bate, Haramaya, and Awaday.

\subsection{Sampling Techniques and Sample Size}

The study used a purposive sampling technique to select the study site (i.e. Bate, Haramaya, and Awaday), and a convenient sampling technique is used to select respondents for interviews and Focus Group Discussion (FGD). A convenient sampling (also known as availability sampling) is a type of non-probability sampling that relies on data collection from population members who are conveniently available to participate in the study area (Creswell, 2009). It also allows the researcher to obtain data and trends without complications, unlike that of a random sample. Twenty-eight interviews were conducted with individuals and the keyinformant, between November 2019 and February 2020.

The individual interviews were conducted with sixteen women (eight married women and eight divorced), to examine the perception and attitude toward domestic violence and reactions on the issues. In addition, twelve key informant interviews were conducted with women officers from the Women, Children, and Youth Affairs office, woreda administration office, Police office, and local women elders called Hada Sike. The key informant interviews were to understand the magnitude of the prevalence of domestic violence in the area. Bernard (2006) indicates that the key-informant interview is vital to easily access and understands important information. Moreover, three FGD, each comprising seven to ten members were conducted to triangulate information.

\subsection{Data Type and Sources}

Primary data was collected using a semi-structured interview with married and divorced women in the community and key-informant interviews with women officers. FGD was also 
employed to triangulate the information on the attitude and perceptions of domestic violence, the magnitude, and types of violence, and women's reactions. The secondary data were obtained from local and international media, magazines, and international reports.

Table 1: Characteristics of the Informants

\begin{tabular}{|c|c|c|c|c|}
\hline No. & Type of variables & Classification & Number & Percentage \\
\hline \multirow{2}{*}{1} & \multirow{2}{*}{ Marriage Status } & Married & 19 & $67.8 \%$ \\
\hline & & Divorced & 9 & $32.1 \%$ \\
\hline \multicolumn{3}{|c|}{ Total } & 28 & $100 \%$ \\
\hline \multirow{4}{*}{2} & \multirow{3}{*}{ Occupation } & Housemaid & 6 & $21.4 \%$ \\
\hline & & Worked in Government office & 13 & $46.4 \%$ \\
\hline & & Worked at NGO & 1 & $3.6 \%$ \\
\hline & & Involved in pity trade & 8 & $28.57 \%$ \\
\hline \multicolumn{3}{|c|}{ Total } & 28 & $100 \%$ \\
\hline \multirow{4}{*}{3} & \multirow{4}{*}{ Educational Status } & Illiterate & 8 & $28.57 \%$ \\
\hline & & Primary & 6 & $21.4 \%$ \\
\hline & & Secondary \& Preparatory & 7 & $25 \%$ \\
\hline & & Tertiary and above & 7 & $25 \%$ \\
\hline \multicolumn{3}{|c|}{ Total } & 28 & $100 \%$ \\
\hline
\end{tabular}

Source: From filed data, 2019

\subsection{Method of Data Analysis}

The qualitative data were analyzed using contextual and textual analysis methods. Accordingly, the data were categorized, synthesized, and presented by using narration, description, and explanation. The researcher summarized data from the interviews with contact summary forms. After each interview, the researcher summarized the previous interviews on a contact summary in the local language (Afan Oromo) before going for the next interview.

\subsection{Ethical Consideration}

To legalize every movement for the research work, the researchers used a formal letter given from Haramaya University's research office. Throughout the activity, social norms (safuu) were followed. The researcher introduced himself before putting forward reasons for the objectives of the research. The researcher started asking open-ended questions and replied to questions depending on the consent and willingness of informants. Informants were assured that the information provided by them would be kept confidential. The questions were prepared first in English and then translated into Afan-Oromo. The researcher and his assistants used Afan Oromoo and Amharic languages considering the language ability of informants.

\subsection{Data Validation Techniques}

To ensure the validity and reliability of the data, different forms of techniques are used like choosing a well-trained and skilled moderator (or facilitator). Moderator checked personal bias and expectations at the door, and the researcher triangulated data from multiple perspectives. Moreover, respondent validation is used to check the researcher's validity. This technique involved testing initial results with participants to see if they still rang true. 


\section{Discussion and Findings}

\subsection{Status of Domestic Gender-based Violence in Eastern Hararghe Zone}

Violence against women is not a recent phenomenon in East Hararghe Zone. The responses indicate that women are aware of domestic violence and observed the practices even before they got married and bore a child. Still, the incidence of this violence has been increasing. Though domestic violence is not only practiced in East Hararghe, women in East Hararghe are living amid harsh situations primarily due to domestic violence perpetrated by their husbands. Due to the dominant culture, which undermines women's interest and capacity, husbands in the area have no interest in their wives' education and economic activities. It is also believed that wife are inferior to their husband and gives respect to them and unless and otherwise, they face social punishment.

The extant literature on domestic gender-based violence also supports this study. GBV has many forms and is practiced by different people, including intimate partners, throughout the world, due to various reasons. Some forms of violence mostly practiced are domestic violence, sexual violence, and feticide or the killing of women because of their gender by males. The frequency and magnitude of GBV vary across countries and continents. Its negative impacts are usually universal, which mostly affect and directly impacts the health of the victims (UNOCHA, 2004).

Besides, a 2005 multicounty study by the WHO, with data taken from 10 countries and 15 sites, found out that the proportion of ever-partnered women who had ever experienced physical or sexual violence, or both, by an intimate partner in their lifetime ranged from $15 \%$ to $71 \%$. In four countries-Bangladesh, Ethiopia, Peru, and Tanzania - at least half of women had ever experienced physical or sexual violence. At least one in three women across the world is estimated to have coerced into sex, physically beaten, and otherwise abused in her lifetime (WHO, 2005).

Moreover, worldwide, an estimated 40 to $70 \%$ of women domestic gender-based violence is committed by their husbands, often in the context of an abusive relationship (Heise \& GarciaMoreno, 2002). Sexual violence within marriage is highly prevalent and considered as normal, with approximately $10-13 \%$ of women reported as having been forced by a partner to have sex against their will at some point in their life (Heise et al., 1999).

Based on the literature, the researcher reveals the status and practices of domestic violence in the selected site of East Haraghe Zone. The majority of the informants claim that they are economically poor and did not attend school due to the pressure imposed by their families and husband. Contrary to this, a few informants claimed that domestic violence is decreasing in the area compared to the past. Which they argued due to the change in the attitude among the community, particularly men group regarding the impacts of the violence through various training given to them by government and non-government organizations at different times.

\subsection{Perception and Attitude of the Community towards Domestic GBV}

Though all individuals had different attitudes and perceptions regarding the practice of violence against women at the domestic level, the understanding was broad and subjective was 
characterized by doing unnecessary things against the interest and consent of the person. Most of the informants had provided a more comprehensive definition of domestic gender-based violence that they experienced by their husbands. It includes physical, sexual, psychological, and emotional dimensions and different controlling behaviours. Even if the forms and degrees vary, the majority of the informants confirmed that violence against women is widespread. In other words, both men and women could be violent, but the attitude and perception of the community dominated by the ideas that: 1) men are the responsible group for domestic violence; 2 ) women are the assaulted group.

Majority informants agreed that domestic violence is not appropriate and acceptable as it harms women in different ways and has a long term impact on their entire life span. Still, they believe that the husband and wife need to live together in peace than living the ocean of conflict. They encouraged husbands and wives to live together peacefully and perform their duties in harmony. They also advised them to solve their common problems through discussion. Nevertheless, it does not mean that all agreed to the idea. Some argued that conflict between husband and wife is one aspect of life, and confirmed as it was, it is, and it will be there forever. They explained that beating, insulting, or dehumanizing their wives is part of a life, acceptable and conflicts as accepted in marriage. After all a man can beat wife, especially when angry. They believed accusing the husband of insulting or beating his wife as denying existing reality.

A few of the informants had also disclosed that domestic violence as positive in the community. Similarly, Demmelash (2012) found that the society takes the husband beating his wife as a cultural practice and recommend the women not to take the case to court, and encouraged them to solve by the community's elder. Three of the informants said that domestic violence is compromised in many families. For example, a woman among FGD informants said:

"It is unthinkable that there is a man who had never been beaten of his wife in Ethiopia."

They took it a routine matter of family life. They argued, if a man does not beat his wife, the community cannot accept him as a man, beating a wife is seen as one of the criteria to identify a strong husband from the weak one. Potentially serious assaults were said to follow often under the suspicion of infidelity and jealousy. The respondents also narrated stories of violent acts ranging from intentional severe burn injuries to murder due to jealousy and other reasons. In the in-depth interviews, survivors of violence said they were slapped, punched, kicked, and beaten with an object. One of the victims mentioned that her husband had broken off her leg; others shared experiences of sexual violence, and forced sex.

In the women's group discussions and individual interviews, participants raised the stories of marital rape. The issues are usually secret, since most of the time, women do not want to talk about these cases because of the cultural taboo. Likewise, no informants in this study disclosed their personal experience of forced sex, instead, they discussed stories of their friends who were bitter with their husbands who pressurised them to have frequent sex, that was caused them pain and "uterine problems." The victims had been suffering from being exposed to these issues. It affected them both physically and psychologically besides the time they had to spend to nurse themselves and recover from the problem they encountered. Not only this, the economic condition of these women deteriorated as time passed. Though these women have a right to the income of their husband and family, much of this income is spent on medical services and on purchasing medicines prescribed by the doctors for their problems. They spend 
the money on such issues instead of spending on other necessities and covering other expenses. Hence, these and other related factors expose them to abject poverty.

Another informant described the experience of her friend who developed a "uterine infection," calling for medical attention, putting her on the verge of divorce due to forced sex. The alleged abuser admitted that there were times he pressured his wife into sex by beating her up, especially when he was drunk.

As IASC (2005) described, the term "gender-based violence" is used alternately with the term "violence against women". These terms highlight the gender dimension of these types of acts; the relationship between women's subordinate status in society and their increased vulnerability to violence. Data gained through in depth interviews from the key informants also confirmed that gender division of labour is one among the other factors triggering domestic violence like shouldering the domestic tasks, failing to provide money for the family and squander women's property. The problem gets worse when the women do not have their income, which is often the case. Men also assert that being the breadwinners of the family, they have the right to shut women up when they ask for money. But even when both the husband and wife are earning, resources are said to be controlled by the husband. For instance, the comments given by a survivor of violence from an FGD were as follows:

"...... to protect my children from hunger, I used to prefer to keep silent while suffering from my husband."

She thought that her husband would not be willing to provide her money if she did not obey him completely, fearing her children would suffer in poverty. She opted to keep silent instead and move on with her life in the face of these challenges.

\subsection{Forms and Magnitude of Domestic Gender-Based Violence in the Study Area}

Women, more often than men, are exposed to different forms of violence due to their gender, and domestic violence is one of those. WHO (2019) indicated that partner violence occurs in all countries and transcends social, economic, religious, and cultural norms. Worldwide, one of the most common forms of violence against women is abuse by their husbands or other intimate male partners. Accordingly, during the FGD, respondents described that violence occurred from a relatively unknown persons who have no close relationship with the victim. But it was agreed that violence is often practiced by a person who has close relations with the victim, especially the husband. The interviewees explained different forms of domestic violence were practiced in the area; the impact they had on the life of women was similar.

The participants of this research confirmed that violence affects the psychological, physical, sexual, and economic condition of the victim. As the study conducted by Yemaneh (2004) revealed, domestic violence takes different forms in Ethiopia. He disclosed that physical, sexual, and emotional assaults occur at alarming rates. All informants of the FGDs confirmed that beating and verbal abuse by the husbands were common practice in the study area. An instance of this is quoted below by one of the women whose mother was killed by her father 8 years ago:

"I used to love my father very much, but with intangible reason, he hit on the head by the so-called Menca and killed my mother eight years ago. Since then, I hate my father and have never talked to him since then." 
She also revealed that her father's action had contributed to change her previous behaviour and impacted her current marriage. The majority of the respondents opined that the husbands used to beat their wives to cool their anger. As the informants of the FGDs pointed out, the other form of domestic gender-based violence widely practiced by their husbands at home but remained unreported was marital rape. The majority of the FGD informants had a favourable attitude towards it, few of the participants in FGDs disapproved of marital rape. Many respondents argued that a man and a woman entered into a marital contract, which they said was a legitimate and voluntary institution, so it would be difficult to talk about forced sex. They said that the wife involved in the party should do sex with her partner.

They strongly believed that sex was the main reason a man and a woman would get married. It was difficult for men not to have sex while sleeping in one bed. There was also an opinion that sexual pleasure is a shared feeling bad for neither of them and, therefore, acceptable. They also explained that a married woman should not refuse to have sex with her partner, as it might push her partner to seek other women to get pleasure and have sex.

\subsection{Kind of Reactions Given by Women Victims of Domestic GBV}

As the outcome of many research conducted on domestic gender-based violence revealed, women who were exposed to the violence usually preferred to keep silent and considered it the best strategy to maintain the relationship they had with their husband and children due to the attitude and perception they inherited from their culture. In this regard, the 2016 demographic and health survey of Ethiopia showed that in many cultures, men have the right to control their wives' behaviour and those women who challenge that right may get punishment. Due to these facts, the aggrieved women usually preferred to keep silent than taking the issue to court. As many FGD respondents said, "they fear the situation might get worse and become out of control and may bring divorce if they took the case to court or any other concerned body. Regarding this, one of the key informants from women local elders called Hadha Siqe said in Afan Oromo: "Haadha manaa fi abbaa manaa haa turuuti Bineensi bosonaayyuu walitti bu'a" which means, "not the disagreement between Husband and Wife who live together, animals in the forest even get into a conflict".

On the other hand, some of the informants from the FGDs disclosed that troubled women sometimes left their house and fled to their family's home as the best option to evade the situation. They thought by doing this, their husbands got alone and failed to look after their children properly. Then, the husband would go to her family's house with some elders for reconciliation. They argued that this strategy proved effective in changing their husband's bad behaviour. Similarly, results obtained from key informants through interviews also testified to the effectiveness of the strategy but doubted its sustainability as the husband would resort to violence after a certain period. Besides that, there were a few informants who disclosed that divorce was also applied as one of the other options to cope with the domestic violence they suffered. For instance, one of the divorced women from the FGDs said:

"I divorced my husband two years ago because he frequently beat me after he was drunk. Now thanks to Almighty God, I am fine and living a healthy life. Even I put some weight after I divorced him. ... Laughs!'”

She explained that even though she was economically affected, she had no regret with her divorce and encouraged other women also who were passing through the same condition to divorce their husbands. 


\section{Conclusion and Recommendations}

GBV is a phenomenon deeply rooted in gender inequality and continues to be one of the most notable human rights violations within all societies. Though both women and men experience GBV, the majority of victims are women and girls. The reasons why GBV and violence against women are often used interchangeably is that most GBV is inflicted on women and girls, by men. Considering the gender aspect is relevant because it highlights the fact that many forms of violence against women are rooted in power inequalities between women and men. Domestic violence, one of the forms of GBV and is an umbrella term that encompasses both Intimate Partner Violence and Family Violence

Violence directed against people because of their gender is the most severe form of discrimination and remains part of everyday life for many living in Africa, particularly Ethiopia and the specific study area. As the finding of this study revealed, the violence has been practiced either by an intimate partner or a non-intimate one. Intimate violence is a pattern of coercive and abusive behaviours used by one partner to maintain power and control over another partner in an intimate relationship. Including people with any current or former romantic involvement, for example, dating, previously dating, on-again/off-again, married, divorced, living together, or apart. As the study indicates, intimate partner violence had occurred between people of any gender identity or sexual orientation and can include manipulation, threats, or the actual use of physical, sexual, emotional, verbal, psychological, or financial abuse.

The outcome of the study showed a different view regarding the perception and attitude of the community towards domestic gender-based violence. The majority of the respondents believe that violence against women is inappropriateness and unacceptability. Still, some of the respondents considered a husband beating his wife as a cultural practice. Moreover, the study also revealed that women use different mechanisms to cope with domestic violence. These are divorce, fleeing from their husband's home to their parents' home, and to remain silent in any harsh situation to overcome the problems. Based on the outcome of the study, the researcher recommends the followings:

a) The act of domestic violence is viewed as an acceptable practice in some cultures. Hence, awareness creation on the impacts of domestic violence is vital. In this regard, involving men and other stakeholders working in the area is necessary.

b) Governmental and non-governmental bodies need to mobilize resources and allocate budget to conduct training to men and women, especially to uneducated men and women on communication skills, domestic gender-based violence, drug abuse, and other issues

c) To end the violence at the grassroots level, women should take the initiative and play a pivotal role in exposing these acts and oppressors to the media to get the media attention. In this regard, they should not be reluctant since they can act as agents to bring about transformation and gender equality in society.

d) Participatory policy development should be adhered to so that the women could be engaged in the process of policymaking, especially related to issues of gender equality and violence against women, to make their voices heard.

e) The legal institution must be reformed to have more powers for dispensing justice and equity by giving an exemplary punishment on incidents of gender-based violence to oppressors or criminals. 
f) The issues like marital rape is usually left unreported, have been adversely affecting the physical, psychological, sexual, and economic conditions of women. It must be reported to get legal attention. The governmental, non-governmental, and other concerned bodies like religious leaders, indigenous elders, and the police should work in coordination.

\section{References}

Berhane, Y. (2004). Ending domestic violence against women in Ethiopia. Ethiopian Journal of Health, 18, 131-132.

Bernand H. (2006). Research Methods in Anthropology: Qualitative and Quantitative Approaches.

https://www.researchgate.net/publication/37420150_Research_Methods_in_Anthropol ogy_Qualitative_and_Quantitative_Approaches

Birtukan G. (2014). Women in policing: the career experiences and advancement opportunities of women officers. MA thesis. Addis Ababa.

Creswell, J. (2009). Research Design Qualitative, Quantitative and Mixed Methods Approach. ( $3^{\text {rd }}$ ed.). SAGE.

Demmelash, F. (2012). Police officers' attitude towards gender-based violence in Kirkos SubCity, Addis Ababa: Institute of Gender Studies, Addis Ababa University (Unpublished M.A Thesis).

Demographic \& Health Survey (2016). Central Statistical Agency: Addis Ababa, Ethiopia. https://dhsprogram.com/pubs/pdf/FR328/FR328.pdf

ECOSOC Humanitarian Affairs Segment (2006). Addressing gender-based violence in humanitarian emergencies: gender-based violence and the role of the UN and its member

https://www.un.org/docs/ecosoc/meetings/2006/docs/Presentation\%20Mr.\%20 Michel.pdf

Garcia-Moreno, C., Heise, L., Jansen, H. A. F. M., Ellsberg, M., \& Watts, C. (2005). Violence against women. Science, 31, 1282-1283.

Gossaye, Y., Deyessa, N., Berhane, Y., Ellsberg, M., Emmelin, M., Ashenafi, M. ... Hogberg, U. (2003). Butajira rural health program: women's health and life events study in rural Ethiopia. The Ethiopian Journal of Health Development, 17(5), 1-40. http://www.cih.uib.no/journals/ejhd

Heise, L., \& Garcia-Moreno, C. (2002). Violence by intimate partners. In Krug, E. G., Dahlberg, L., Mercy, J. A., Zwi, A. B., \& Lozano, R. (Eds.). World report on violence and health. Geneva: World Health Organization.

Heise, M., Ellsberg, D., \& Gottmoeller B. (1999). A global overview of gender-based violence. https://pubmed.ncbi.nlm.nih.gov/12429433/

Hiba, M. (2018). The Vulnerability of Women Refugees to Gender-Based Violence (GBV): A Case of Addis Ababa A Thesis Submitted to the Center for Human Rights in Partial Fulfillment of the Requirements for the Degree of Master of Arts in Human Rights http://bit.ly/2Cm9uh3

I ARBCI, (2004). Assessment on the Impacts of Gender-Based Violence. Retrieved from: https://www.irb-cisr.gc.ca/en/Pages/index.aspx

IASC (2005, September 1). Guidelines for Gender-based Violence Interventions in Humanitarian Settings. Focusing on Prevention of and Response to Sexual Violence in Emergencies. Geneva. https://interagencystandingcommittee.org/iasc-sub- 
working-group-gender-and-humanitarian-action/iasc-guidelines-gender-basedviolence

Istanbul Convention (2011). Forms of Violence. European Institute for Gender Equality: Council of Europe, Convention on Preventing and Combating Violence against Women and Domestic Violence. Istanbul, Turkey.

Jeffreys, S. (2014). Gender hurts: A feminist analysis of the politics of transgenderism. Routledge.

Marcia L. (2006). The relationship between Gender and Anthropology. Waveland.

Ruth, K. (2017). Police Response to Intimate Partner Violence against Women. A master's thesis submitted to Addis Ababa University - Centre of Gender Studies.

UNFPA (2017). Gender-based violence. https://www.unfpa.org/gender-based-violence

UNOCHA (2004). Our Bodies - Their Battle Ground: Gender-based Violence in Conflict Zones. http://www.irinnews.org /web specials/gbv/print/p-Definitions.asp

WHO (2019). Sexual and Reproductive Health. https://www.who.int/reproductivehealth/topics/violence/en/

Yemaneh B., 2004). Intimate partner violence and depression among women in rural Ethiopia: a cross-sectional study. Ethiopia, Addis Ababa.

\section{Appendixes}

List of Informants

\begin{tabular}{|c|c|c|c|c|}
\hline No. & $\begin{array}{l}\text { Name of the } \\
\text { Informant }\end{array}$ & Sex & $\begin{array}{l}\text { Place \& Date } \\
\text { of Interview }\end{array}$ & emark \\
\hline 1 & $\begin{array}{l}\text { Birhane } \\
\text { Shiferaw }\end{array}$ & $\mathrm{F}$ & $\begin{array}{l}\text { Haramaya, } \\
\text { 01kebele, } \\
\text { 28-11-2019 } \\
\end{array}$ & $\begin{array}{l}\text { She is } 42 \text { years old. She came from Chiro in 2004G.C and currently } \\
\text { working as police officer. She attended high school and she is } \\
\text { married. }\end{array}$ \\
\hline 2 & $\begin{array}{l}\text { Caltu } \\
\text { Mohammed }\end{array}$ & $>$ & $\begin{array}{l}\text { Awaday, } \\
01 \text { kebele, } \\
20-1-2020\end{array}$ & $\begin{array}{l}\text { She is } 38 \text { years old and has experienced about the violence though } \\
\text { she did not divorced yet. She is currently staff in city administrative } \\
\text { office and diploma holder }\end{array}$ \\
\hline 3 & Fatiya Jibril & $>$ & $\begin{array}{l}\text { Babile, } \\
02 \text { kebele } \\
28-11-2019\end{array}$ & $\begin{array}{l}\text { She is } 42 \text { years old. She has been living there by selling a charcoal } \\
\text { on the street almost for } 7 \text { years. She is one of the victims and } \\
\text { divorced her husband } 8 \text { years ago with issue related to this } \\
\text { violation. She did not went to school }\end{array}$ \\
\hline 4 & $\begin{array}{l}\text { Fatuma Aba } \\
\text { Macha }\end{array}$ & $\gg$ & $\begin{array}{l}\text { Babile, } \\
01 \text { kebele } \\
28-11-2019\end{array}$ & $\begin{array}{l}\text { She is } 43 \text { years old and married for third time. She has a problem } \\
\text { with doing sexual intercourse. She is currently serving as a } \\
\text { messenger in the administration office of the town. She has } \\
\text { completed high school }\end{array}$ \\
\hline 5 & $\begin{array}{l}\text { Fayise } \\
\text { Kafani }\end{array}$ & $>$ & $\begin{array}{l}\text { Haramaya, } \\
02 \text { kebele, } \\
28-11-2019\end{array}$ & $\begin{array}{l}\text { Fayise is } 41 \text { years old. She did not attend school and living her life } \\
\text { by selling different forms of fruits on the street. She informally } \\
\text { divorced her husband and re-engaged with him. }\end{array}$ \\
\hline 6 & Fayo Ahmed & $\gg$ & $\begin{array}{l}\text { Awaday, } \\
02 \text { kebele, } \\
20-1-2020\end{array}$ & $\begin{array}{l}\text { She is } 36 \text { years old. She born in Galamso and currently works in } \\
\text { city's administrative Office. She is BA holder in Sociology }\end{array}$ \\
\hline 7 & Gudatu Abdi & $>$ & $\begin{array}{l}\text { Awaday, } \\
01 \text { kebele, } \\
28-11-2019 \\
\end{array}$ & $\begin{array}{l}\text { She is } 32 \text { years old. She born at a place called Kobo and currently } \\
\text { working in women, children and youth office. She is Diploma } \\
\text { holder. She divorced her husband three years ago. }\end{array}$ \\
\hline 8 & Habiba Siraj & $>$ & $\begin{array}{l}\text { Awaday, } \\
02 \text { kebele, } \\
28-11-2019\end{array}$ & $\begin{array}{l}\text { Habiba is } 23 \text { years old. She is living by selling a chat on the street. } \\
\text { She divorced her husband two years age. She attended primary } \\
\text { school }\end{array}$ \\
\hline 9 & Halima Aliye & $>$ & $\begin{array}{l}\text { Haramaya, } \\
02 \text { kebele, } \\
20-1-2020\end{array}$ & $\begin{array}{l}\text { Halima is } 29 \text { years old. She divorced her husband } 9 \text { years ago } \\
\text { because of her husband beat her and broke her left hand and } \\
\text { remarried for a second time. She works in the town's office } \\
\text { administration and degree holder }\end{array}$ \\
\hline
\end{tabular}




\begin{tabular}{|c|c|c|c|c|}
\hline 10 & $\begin{array}{l}\text { Indisar } \\
\text { Abdurhaman }\end{array}$ & & $\begin{array}{l}\text { Awaday, } \\
01 \text { kebele, } \\
\text { 28-11-2019 }\end{array}$ & $\begin{array}{l}\text { She is } 49 \text { years old. She is one of the respected women in the area } \\
\text { and has been serving as one of the reconciliatory women in the } \\
\text { area. She attended primary school and currently married and } \\
\text { housemaid }\end{array}$ \\
\hline 11 & $\begin{array}{l}\text { Jemila } \\
\text { Amiye }\end{array}$ & $\gg$ & $\begin{array}{l}\text { Haramaya, } \\
01 \text { kebele, } \\
28-11-2019\end{array}$ & $\begin{array}{l}\text { She born and grew up there. Currently, she is } 34 \text { years old. She } \\
\text { knows about the issue very well and even she experienced and } \\
\text { divorced her husband due to the violence. She is working in police } \\
\text { office and completed grade } 10\end{array}$ \\
\hline 12 & $\begin{array}{l}\text { Kedija } \\
\text { Ahmed }\end{array}$ & $\gg$ & $\begin{array}{l}\text { Haramaya, } \\
01 \text { kebele, } \\
18-12-2019\end{array}$ & $\begin{array}{l}\text { She is } 24 \text { years old. She attended a primary school and working as } \\
\text { cleaner in office of women, children and youth office. She lost one } \\
\text { of her teeth by her husband, but still living with him. }\end{array}$ \\
\hline 13 & $\begin{array}{l}\text { Kulani } \\
\text { Ahmed }\end{array}$ & $\gg$ & $\begin{array}{l}\text { Haramaya, } \\
01 \text { kebele, } \\
20-1-2020\end{array}$ & $\begin{array}{l}\text { She is } 49 \text { years old. She has been living there by engaging on petty } \\
\text { trade (small shop) almost for 5years. She is one of the victims of } \\
\text { domestic gender-based violence. She is married and not attended } \\
\text { any school. }\end{array}$ \\
\hline 14 & Lome Bado & $>$ & $\begin{array}{l}\text { Babile, } \\
01 \text { kebele } \\
20-11-2019 \\
\end{array}$ & $\begin{array}{l}\text { She is } 36 \text { years old. She came from Adama and working in Care } \\
\text { Ethiopia. She is BSc. holder in nursing and married }\end{array}$ \\
\hline 15 & Meti Tofik & $\gg$ & $\begin{array}{l}\text { Babile, } \\
01 \text { kebele, } \\
28-11-2019\end{array}$ & $\begin{array}{l}\text { She is working as housemaid and not attended any school. She is } 33 \\
\text { years old. She divorced her husband } 3 \text { years ago. }\end{array}$ \\
\hline 16 & $\begin{array}{l}\text { Misire } \\
\text { Mitiku }\end{array}$ & $>$ & $\begin{array}{l}\text { Babile, } \\
01 \text { kebele } \\
20-11-2019\end{array}$ & $\begin{array}{l}\text { Misire is } 28 \text { years old. She is working in civil service office at } \\
\text { Babile. She has two children and one of the victims of domestic } \\
\text { gender based violence. She faced with hearing difficulty with one } \\
\text { of her ear by her husband three years ago, but still living with him. } \\
\text { She is Diploma holder }\end{array}$ \\
\hline 17 & $\begin{array}{l}\text { Momina } \\
\text { Magarsa }\end{array}$ & $\gg$ & $\begin{array}{l}\text { Babile, } \\
01 \text { kebele, } \\
20-11-2019 \\
\end{array}$ & $\begin{array}{l}\text { She is } 28 \text { years old. She is working in city's women, children and } \\
\text { youth office. She attended preparatory school and married. }\end{array}$ \\
\hline 18 & $\begin{array}{l}\text { Sartu } \\
\text { Mohammed }\end{array}$ & $>$ & $\begin{array}{l}\text { Haramaya, } \\
02 \text { kebele, } \\
28-11-2019\end{array}$ & $\begin{array}{l}\text { She is } 28 \text { years old. She engaged on petty trade and has } 4 \text { children. } \\
\text { She did not attended any school and married }\end{array}$ \\
\hline 19 & $\begin{array}{l}\text { Sifan } \\
\text { Ahmednur }\end{array}$ & $\gg$ & $\begin{array}{l}\text { Awaday, } \\
02 \text { kebele, } \\
18-12-2019\end{array}$ & $\begin{array}{l}\text { Sifan is } 36 \text { years old and she attended preparatory school. She } \\
\text { dropped the school at grade } 9 \text { when she got married with her ex- } \\
\text { husband. Now she re-married and living with her second husband. } \\
\text { She has four children (one from the former and three from her } \\
\text { current husband). She is housemaid. }\end{array}$ \\
\hline 20 & Sifan Geleto & $\gg$ & $\begin{array}{l}\text { Haramaya, } \\
01 \text { kebele, } \\
18-12-2019\end{array}$ & $\begin{array}{l}\text { She is } 44 \text { years old and living with her husband almost for } 18 \text { years } \\
\text { without any problem. She has seven children. She is a respected } \\
\text { woman around the area and engaged in the local arbitration process. } \\
\text { She attended primary education }\end{array}$ \\
\hline 21 & $\begin{array}{l}\text { Sinaf } \\
\text { Amansisa }\end{array}$ & $>$ & $\begin{array}{l}\text { Haramaya, } \\
01 \text { kebele, } \\
20-1-2020\end{array}$ & $\begin{array}{l}\text { She is working as a cleaner at Haramaya Hospital and attended a } \\
\text { primary school. She is } 38 \text { years old. She divorced her husband one } \\
\text { year ago. }\end{array}$ \\
\hline 22 & $\begin{array}{l}\text { Sofiya } \\
\text { Abdukarim }\end{array}$ & $\gg$ & $\begin{array}{l}\text { Awaday, } \\
01 \text { kebele, } \\
20-1-2020\end{array}$ & $\begin{array}{l}\text { She came from Gara Mulata and living there almost for } 15 y e a r s . \text { She } \\
\text { has been serving as Hadha Siqe to reconciliatory when such issue } \\
\text { happens. She is married and not attended any school. }\end{array}$ \\
\hline 23 & $\begin{array}{l}\text { Tolani } \\
\text { Bayissa }\end{array}$ & $\gg$ & $\begin{array}{l}\text { Awaday, } \\
02 \text { kebele } \\
18-12-2019 \\
\end{array}$ & $\begin{array}{l}\text { She is working as guard of CBE and attended high school. She is } 32 \\
\text { years old. She is married. }\end{array}$ \\
\hline 24 & $\begin{array}{l}\text { Workinesh } \\
\text { Galata }\end{array}$ & $\gg$ & $\begin{array}{l}\text { Haramaya, } \\
01 \text { kebele, } \\
18-12-2019 \\
\end{array}$ & $\begin{array}{l}\text { She is a police officer. Her age is } 34 \text { and lived there for more than } 8 \\
\text { years. She is marred. She attended high school. }\end{array}$ \\
\hline 25 & Wude Yasuf & $\gg$ & $\begin{array}{l}\text { Babile, } \\
01 \text { kebele, } \\
18-12-2019\end{array}$ & $\begin{array}{l}\text { Wude is } 37 \text { years old. She divorced her husband two years ago and } \\
\text { he has three children. She attended preparatory school and engaged } \\
\text { on small shop. }\end{array}$ \\
\hline
\end{tabular}




\begin{tabular}{|c|l|l|l|l|}
\hline \multirow{2}{*}{26} & $\begin{array}{l}\text { Zaytuna } \\
\text { Abdala }\end{array}$ & >> & $\begin{array}{l}\text { Babile, } \\
02 \text { kebele, } \\
18-12-2019\end{array}$ & $\begin{array}{l}\text { She is 27 years old and divorced her husband one year ago. } \\
\text { Currently, she is living with her family together with her son. She } \\
\text { attended high school and engaged on pity trade. }\end{array}$ \\
\hline \multirow{2}{*}{27} & Zebiba Haji & >> & $\begin{array}{l}\text { Babile, } \\
01 \text { kebele, } \\
18-12-2019\end{array}$ & $\begin{array}{l}\text { She is working as secretary in women, children and youth office of } \\
\text { the town. Her age is 34 and lived there for more than 8 years, and } \\
\text { she is BA holder in gender and development. She is married. }\end{array}$ \\
\hline \multirow{2}{*}{28} & $\begin{array}{l}\text { Zeyituna } \\
\text { Mohammed }\end{array}$ & \multirow{2}{*}{ >> } & $\begin{array}{l}\text { Awaday, } \\
01 \text { kebele } \\
18-12-2019\end{array}$ & $\begin{array}{l}\text { She is 48 years old. She did not attend any school and living with } \\
\text { remittances sent by her children from United Arab Emirates. She } \\
\text { divorced her husband four years ago. }\end{array}$ \\
\hline
\end{tabular}

\section{Prepared Interview Guideline for Informants (for Semi-structured Interview)}

Haramaya University

College of Social Sciences and Humanities

Department of Gender and Development Studies

Date:

Place of Interview:

Name of the Informant:

Age of the Informant:

Marriage Status:

Educational Background:

Current Type of Occupation:

\section{Main Questions (For In-depth Interview)}

What is domestic gender-based violence for you?

Is there a practice of domestic gender-based violence around your local area?

How do you understand the perception and attitude of the community regarding to domestic gender-based violence, especially the act of violation that are made between husband and wife?

What forms of domestic gender-based violence are practising around the area where you are currently living?

Have you ever seen when husband beats, kick, punch, slap their wife?

How husband and wife solve their problem when they get into conflict?

What kinds of mechanisms are implemented as a best solution by the women during domestic gender-based violation, especially by their husbands?

\section{INTERVIEW GUIDLINE FOR FOCUS GROUP DISCUSSION (FGD)}

1. Think back to the years you were living with your husband (for those divorced) for a minute and tell me what do you feel about the situation?

2. How do you relate women's domestic violation with poverty?

3. Do you think women's economic empowerment could address/reduce women's domestic violence, especially that come from their husbands?

\section{FOR KEY-INFORMANTS}

1. Do you think husband is the only one who engaged in the violation?

2. What do you think about the magnitude of the violence?

3. What kinds of policy interventions have been taken by government particularly by your institution?

4. What is your recommendation to alleviate the issue as an expert? 